\title{
Effect of plant diversification on pest abundance and tomato yields in two cropping systems in Burkina Faso: farmer practices and integrated pest management
}

\author{
Diakalia SON ${ }^{1,3^{*}}$, Irénée SOMDA ${ }^{1}$, Anne LEGREVE ${ }^{2}$ and Bruno SCHIFFERS ${ }^{3}$ \\ ${ }^{1}$ Université Nazi Boni (UNB), Institut du Développement Rural (IDR), Unité Santé des Plantes du Laboratoire \\ Systèmes Naturels, Agrosystèmes et Ingénierie de l'Environnement (Sy.N.A.I.E), 01 BP1091 Bobo-Dioulasso, \\ Burkina Faso. \\ ${ }^{2}$ Université Catholique de Louvain (UCL), Faculté des Bioingénieurs, Earth and Life Institute, Croix du Sud, 2 \\ bte L7.05.03, B-1348-Louvain-la-Neuve, Belgium. \\ ${ }^{3}$ Gembloux Agro-Bio Tech/ULIEGE, Laboratoire de Phytopharmacie Passage des Déportés 2, 5030 \\ Gembloux, Belgium. \\ *Corresponding author; E-mail: sondiakalia@yahoo.fr
}

\section{ACKNOWLEDGEMENTS}

This study was conducted with the financial support of ARES-CDD (PIC Project "Projet de renforcement des capacités de diagnostic et de gestion intégrée des problèmes phytosanitaires au Burkina Faso", UCL-ULg-IDR/UNB).

\begin{abstract}
In Burkina Faso, pests are the main constraint to tomato production because they can cause a complete loss of yields. To protect their crops, producers use extensively chemical pesticides. However, this method can be ineffective and creates collateral effects on public health and on environment. To mitigate this problem, Integrated Pest Management (IPM) trials based on tomato crop in association with basil, garlic or onion were compared with the usual practices of producers in field trials in 2017. The tomato-onion association provided both the best protection of the fruits and the highest yield $\left(3 \mathrm{~kg} / \mathrm{m}^{2}\right)$ compared with peasant and other IPM practices. No pesticide residue was detected in samples (tomatoes and soils) from IPM practices. However, several active substances (profenofos, lambda-cyhalothrin and chlorpyrifos-ethyl) were detected in samples from farmers' practices. Only chlorpyrifos-ethyl showed a residue level above its Maximum Residue Limit (MRL) in tomatoes (360\% of MRL), without acute intoxication risk for consumers according to the calculations of the Predictable Short Term Intake (PSTI). Awareness-raising and producer training on the better agricultural and phytosanitary practices are necessary to protect public health and environment against adverse effects of pesticides in Burkina Faso.
\end{abstract}

(C) 2018 International Formulae Group. All rights reserved.

Keywords: Tomato, peasant practices, IPM, cultural association, Burkina Faso.

\section{INTRODUCTION}

In Burkina Faso, tomato is the second vegetable crop after onion. Its production was estimated at 289,572 tons on $11,766.4$ ha during the 2013-2014 vegetable season (MARHASA, 2014). However, this 
production is limited by many constraints such as pest pressure, early drying of water supplies and a high cost for inputs (seeds, pesticides, fertilizers). Among these major constraint, pest pressure is predominant and the responsible agents in Burkina Faso and other countries like Benin are mainly: whiteflies (Bemisia tabaci Gennadius), caterpillars (Helicoverpa armigera Hübner) and tomato leafminer (Tuta absoluta Meyrick) (Chougourou et al., 2012; Ouattara et al., 2017; Son et al., 2017a). To achieve profitable yields economically, producers intensify (most often arbitrarily) chemical treatments leading to overdosing and increasing number of treatments despite recommendations on labels of plant protection products (Son et al., 2017b). This increasing and unjustified use of pesticides, affects directly farmers health because they do not use personal protective equipment (PPE) during handling and spraying (Ouattara et al., 2010; Tarla et al., 2013; Son et al., 2017b). This misuse of pesticides can also threaten the health of consumers and environment with risks of pesticide residues in vegetables and concomitantly, water and soils (Fernandes et al., 2010; Naré et al., 2015; Lehmann et al., 2017). Also, this unreasoned practices quickly leads to pest resistance to pesticides and the vicious circle of increasing doses and number of treatments (Martin et al., 2000; Brévault et al., 2007).

In order to mitigate the problem of pesticide exposure and the development of insect resistance to insecticides, it is recommanded to use chemicals only at last resort. This system can be achieved only by combining different control methods namely the use of healthy seeds, the choice of resistant cultivars, production of healthy plants in nurseries, balanced nutrition of plants, diversification of production in the same plot, frequent observations at the field level, etc. When plants are diversified in the same plot, pests have more difficulties in locating their host and the diversity favors the presence of pests natural enemies (Hilje et al., 2001; Hooks and Johnson, 2003; Parker et al., 2013). Furthermore, host-hiding and encouragement of natural enemies depress the development of pest populations, reducing the need to pesticide resort increasing crop yields (Parker et al., 2013). Schuster (2004) showed a reduction of $B$. tabaci populations when tomato plot was surrounded by Marrows. Medeiros et al. (2009) showed that intercropping (tomato-coriander association), favored a greater diversity of predatory arthropods, coinciding with the peak of $T$. absoluta populations.

The purpose of this study was to test alternative control strategies that could reduce the use of pesticides in tomato cultivation in Burkina Faso by comparing peasant practices (PP) with integrated pest management (IPM) approaches based on the cultural associations of tomatoes with aromatic plants: basil (Ocimum basilicum L.), garlic (Allium sativum L.) or onion (Allium cepa L.). The aromatic plants were selected to be associated with tomato crops, because they have a high added value for producers and can protect host plant against their pests (Auger et al., 2002; Dross, 2012; Rhino et al., 2014; Khafagy, 2015).

\section{MATERIALS AND METHODS Field trials}

The trials were conducted by four tomato producers in two main markets gardening sites of Bobo-Dioulasso : Kuinima $\left(\mathrm{N}=11^{\circ} 08.393^{\prime} ; \mathrm{W}=004^{\circ} 19.068^{\prime}\right)$ and Kodéni $\left(\mathrm{N}=11^{\circ} 07.993^{\prime}\right.$; $\left.\mathrm{W}=004^{\circ} 18.983^{\prime}\right)$. The trial took place during the dry season (end of December 2016 to April 2017) where the minimum temperature is $30^{\circ} \mathrm{C}$ with an average relative humidity of $32 \%$. The soil is hydromorphic type with silty clay texture and the main crops produced in these sites were tomato, cabbage, onion, lettuce, green bean, pepper and amaranth.

The plants used consisted of tomato, basil, garlic and onion for Integrated Pest Management (IPM) practices and tomato plus lettuce for peasant practices (PP). The tomato variety used in IPM was the cv. "LINDO F1". This variety is reported to have a resistance to bacterial wilt (Ralstonia solanacearum), Tobacco Mosaic Virus (TMV) and Fusarium oxysporum f. sp. lycopersici according to 


\section{"TECHNISEM" Company (France),} responsible for vegetable seed productions which are sold in Burkina Faso by NAKOSEM Company (TECHNISEM, 2016). In the present study, the tomato variety has a cycle from 65 to 70 days and a potential yield of 40-60 T/ha. The onion variety used is cv. "VIOLET DAMANI". Its sowing-maturity cycle is $100-110$ days with a potential yield of 30-40 T/ha (TECHNISEM, 2016). Basil cultivar used is the "GRAND VERT". Arabaci and Bayram (2004) reported an average yield of $419.5 \mathrm{~kg}$ green herb /ha for Ocimum basilicum L. As garlic seeds were not available in Burkina Faso, garlic cloves were bought at the market for seedling. The tomato variety used in peasant practices is the cv. "TROPIMECH" which is known to be highly productive (more than $160 \mathrm{~T} / \mathrm{ha}$ ) but very sensitive to diseases, namely Fusarium, bacterial wilt and to whiteflies (TECHNISEM, 2016). Lettuce was associated with tomato in PP plots. Seeds were produced by the producers themselves who had not any information on the variety and expected yields.

In each site, the trials were carried out with two producers: one for PP and another for IPM. The experimental device in each trial (or site) was a Fischer block completely randomized, with 5 treatments and 3 replicates per treatment (randomized blocks). In each block, each elementary plot measured $20 \mathrm{~m}^{2}$. The blocks were separated by a distance of 0.5 $\mathrm{m}$. The 5 treatments in each site were: PP (reference); tomato alone (T); tomato with basil $(\mathrm{T}+\mathrm{B})$; tomato with garlic $(\mathrm{T}+\mathrm{G})$ and tomato with onion $(\mathrm{T}+\mathrm{O})$.

In the peasant plots, each producer conducted his crops according his usual technique from nursery to harvest (PP) and all operations have been systematically recorded. The average spacings in PP was $20 \mathrm{~cm}$ x 20 $\mathrm{cm}$. The number of plants was 360 plants (producer 1 - PP1) and 420 at producer 2 (PP2) for the same surface $\left(60 \mathrm{~m}^{2}\right)$.

In the IPM plots (also of $60 \mathrm{~m}^{2}$ ), all cropping operations were carried out in the same way at both sites under our control. Basil, garlic and onion plants were transplanted in interlining two weeks before tomatoes to favour their protective role. In the IPM plots, tomato plants were spaced at 40 $\mathrm{cm} \times 70 \mathrm{~cm}$, i.e. 75 plants per block and 225 plants per treatments.

\section{Characteristics of the plant protection products used in PP and IPM}

The plant protection products (PPP) used for the peasant and IPM practices are listed in Table 1. In PP plots, farmers chose the PPPs they will use. Nevertheless in IPM plots, the choice of PPPs was determined according to the pests present on the sites by us.

In the PP plots, producers applied PPP according to their methods, but in IPM plots, the decision to applied PPP was based on observations and assessments made on the plots (Table 2). Pesticides have been applied with the backpack sprayer (15 L tank).

\section{Entomofauna collection and assessment of infestation level}

In each object (PP and IPM), two yellow water traps $(\varnothing=27 \mathrm{~cm}, \mathrm{~h}=10 \mathrm{~cm})$ were installed for collecting entomofauna. The observations of insects began two weeks after transplanting of tomatoes (35 days after sowing). In IPM, the monitoring of whiteflies was perfomed on 15 plants per treatment and on each plant 3 leaves were considered. For $H$. armigera caterpillars, the observations began 4 weeks after transplanting and were carried out on flowers, leaves and fruits. Fifteen plants were retained per practices. The observations were made weekly and carried out early morning (between 6:00 am and 8:00 am) when whiteflies were particularly less active and easier to spot and count (Ofori et al., 2014).

Parts of plants with necrosis, burns, rots, etc. that have been observed as symptoms of disease were analyzed at Plant Pathology Laboratory (Clinique des Plantes) of the Institute of Rural Development at the Nazi Boni University (Burkina Faso) to identify the causal agent. 


\section{Evaluation of yields of different practices (PP and IPM)}

Assessments of healthy or damaged fruits and net yields were performed at each harvesting period. The average unit weight (U, in $\mathrm{kg}$ ) of tomatoes was determined in order to calculate the Predictable Short Term Intake (PSTI). The economic yield was assessed by evaluating the cost of expenditures (fertilizers, seeds, water, PPP treatments, etc.) in relation to sales of tomato and associated crops.

\section{Assessment of pesticide residues in vegetables, water and soils}

Ten samples of tomatoes fruit, water and soil were collected to analyze pesticide residues by PRIMORIS (formerly FYTOLAB, Technologiepark 2/3, 9052 Zwijnaarde, Belgium) laboratory holding a BELAC (Belgian Accreditation Council) accreditation to ISO/CEI 17025 for pesticide residues. PRIMORIS is an independent, accredited, and officially recognized service laboratory (accreditation number 057-TEST). Samples were analyzed with a multi-residue (QuEChERS) method validated by the laboratory for analysis of residues in foodstuffs, which will detect approximately 500 different active substances in a single analysis thanks to a combination of GCMS/MS and LC-MS/MS chromatography. The QuEChERS method is based on work done and published by Anastassiades et al. (2003). For almost all active substances, the limit of quantification (LOQ) was $\leq 0.01 \mathrm{mg} / \mathrm{kg}$. Tomatoes were harvested on 15 plants in each plot and mixed before constituting a final sample of $1 \mathrm{~kg}$ which was placed in a sterile sachet with references of practices and the collection date. Water samples (1 liter) were taken from the gardening bore wells and placed in previously sterilized bottles. Ten soil samples were taken at random with auger at 1 $\mathrm{cm}$ depth in each plot, thoroughly mixed and sorted of vegetal debris and pebbles before constituting a final sample of $500 \mathrm{~g}$ which was placed in an opaque plastic bags. All samples were sent to the Belgian lab immediately after sampling in a delay of max 3 days.

\section{Risk assessment for consumers to pesticide residues}

The risk of ingesting a foodstuff containing pesticide residues that exceeds the Maximum Residue Limit (MRL) is assessed in the worst case scenario by calculating the Predictable Short Term Intake (PSTI). The values obtained were compared with the Acute Reference Dose (ARfD). If PSTI is greater than $\mathrm{ARfD}$, an acute intoxication risk for the group (children or adults) should be considered.

$$
\mathbf{P S T I}=\frac{(\mathbf{U} * \mathbf{O R} * \mathbf{v})+(\mathbf{L P}-\mathbf{U}) * \mathbf{O R} * \mathbf{P f}}{\mathbf{b W}}
$$

with

$\mathrm{U}=$ unit (unit weight of food) in $\mathrm{kg}$;

$\mathrm{OR}=$ observed residue, $\mathrm{mg} / \mathrm{kg}$;

$\mathrm{v}=$ variability factor represents the ratio of the $97.5^{\text {th }}$ percentile residue to the mean residue in single units (according to $\mathrm{U}$ ) (e.g. $\mathrm{v}=7$ if $25<$ $\mathrm{U}<250 \mathrm{~g}$ );

LP $=$ highest large portion provided $\left(97.5^{\text {th }}\right.$ percentile of eaters), in $\mathrm{kg}$ of food per day; $\mathrm{Pf}=$ processing factor represents the ratio of the concentration of pesticide residues in the processed product to the concentration of pesticide residues in the raw product; $\mathrm{bw}=$ body weight for children or adults, in $\mathrm{kg}$.

The MRL values, toxicological and ecotoxicological characteristics of active substances have been collected in various databases (European pesticides database, SAgE pesticides, Agritox, INERIS, JMPR, US EPA....).

\section{Statistical analyses}

The results were subjected to two-way analysis of variance (ANOVA) after verification of the normality of the data (Shapiro-Wilk test) with the GenStat software, edition 11. The mean differences were compared by pair with the Tukey HSD test at $5 \%$ significance level. 
Table 1: List of plant protection products used on tomatoes in PP and IPM plots.

\begin{tabular}{|c|c|c|c|c|}
\hline Practices & Commercial name & Composition & $\begin{array}{l}\text { Recommended dose on } \\
\text { labels }\end{array}$ & Area of use \\
\hline \multirow{5}{*}{ PP1 } & ACARIUS 018 EC & Abamectin $(18 \mathrm{~g} / \mathrm{l})$ & $1 \mathrm{~L} / \mathrm{ha}$ & Allowed against insects and mites on vegetables. \\
\hline & TITAN 25 EC & Acetamiprid $(25 \mathrm{~g} / \mathrm{l})$ & $1 \mathrm{~L} / \mathrm{ha}$ & Authorised against thrips, mites, whiteflies, aphids. \\
\hline & BIO K 16 & $\begin{array}{c}B t \text { var. kurstaki: } \\
2-4 \%(16.000 \mathrm{UI} / \mathrm{mg})\end{array}$ & $1.5 \mathrm{~g} / \mathrm{ha}$ & $\begin{array}{l}\text { Authorised against leaf miners and caterpillars of } \\
\text { Noctuidae. }\end{array}$ \\
\hline & LAMBDA POWER & $\begin{array}{l}\text { Lambda-cyhalothrin } \\
\qquad(25 \mathrm{~g} / \mathrm{l})\end{array}$ & $0.8 \mathrm{~L} / \mathrm{ha}$ & $\begin{array}{l}\text { Authorised against thrips, mites, whiteflies, aphids on cotton } \\
\text { and vegetables. }\end{array}$ \\
\hline & DURSBAN B168 EC & Chlorpyrifos-ethyl $(150 \mathrm{~g} / \mathrm{l})+$ Cyfluthrin $(18 \mathrm{~g} / \mathrm{l})$ & $1 \mathrm{~L} / \mathrm{ha}$ & $\begin{array}{l}\text { Permitted against thrips, whiteflies, aphids and } \\
\text { phyllophagous caterpillars, carpophages on cotton. }\end{array}$ \\
\hline \multirow{5}{*}{ PP2 } & ACARIUS $018 \mathrm{EC}$ & Abamectin (18g/l) & $1 \mathrm{~L} / \mathrm{ha}$ & Allowed against insects and mites on vegetables. \\
\hline & TITAN 25 EC & Acetamiprid $(25 \mathrm{~g} / \mathrm{l})$ & $1 \mathrm{~L} / \mathrm{ha}$ & Authorised against thrips, mites, whiteflies, aphids. \\
\hline & BIO K 16 & $\begin{array}{c}B t \text { var. kurstaki: } \\
2-4 \%(16.000 \mathrm{UI} / \mathrm{mg})\end{array}$ & $1.5 \mathrm{~g} / \mathrm{ha}$ & $\begin{array}{l}\text { Authorised against leaf miners and caterpillars of } \\
\text { Noctuidae. }\end{array}$ \\
\hline & DURSBAN B168 EC & Chlorpyrifos-ethyl $(150 \mathrm{~g} / \mathrm{l})+$ Cyfluthrin $(18 \mathrm{~g} / \mathrm{l})$ & $1 \mathrm{~L} / \mathrm{ha}$ & $\begin{array}{l}\text { Permitted against thrips, whiteflies, aphids and } \\
\text { phyllophagous caterpillars, carpophages on cotton. }\end{array}$ \\
\hline & $\begin{array}{l}\text { LAMBDACAL P } 636 \\
\text { EC }\end{array}$ & Lambda-cyhalothrin $(36 \mathrm{~g} /)+$ Profenofos $(600 \mathrm{~g} / \mathrm{l})$ & $0.334 \mathrm{~L} / \mathrm{ha}$ & $\begin{array}{l}\text { Permitted against thrips, whiteflies, aphids and } \\
\text { phyllophagous caterpillars, carpophages on cotton. }\end{array}$ \\
\hline \multirow{4}{*}{ IPM } & ACARIUS $018 \mathrm{EC}$ & Abamectin (18g/l) & $1 \mathrm{~L} / \mathrm{ha}$ & Allowed against insects and mites on vegetables. \\
\hline & TITAN 25 EC & $\begin{array}{l}\text { Acetamiprid } \\
(25 \mathrm{~g} / \mathrm{l})\end{array}$ & $1 \mathrm{~L} / \mathrm{ha}$ & Authorised against thrips, mites, whiteflies, aphids. \\
\hline & BIOPIQ & $0.6 \%$ Matrine & $1 \mathrm{~L} / \mathrm{ha}$ & Authorised against mites, aphids, whiteflies, thrips, jassids \\
\hline & BIO K 16 & $\begin{array}{l}B t \text { var. kurstaki: } \\
2-4 \%(16.000 \mathrm{UI} / \mathrm{mg})\end{array}$ & $1.5 \mathrm{~g} / \mathrm{ha}$ & Authorised against leaf miners and caterpillars of Noctuidae. \\
\hline
\end{tabular}

PP1: peasant practices for the first producer; PP2: peasant practices for the second producer; IPM: Integrated pest management. 
Table 2: Monitoring of evolution of the pests population in IPM plots.

\begin{tabular}{|c|c|c|c|c|c|}
\hline Pests & $\begin{array}{c}\text { Observation } \\
\text { Period }\end{array}$ & $\begin{array}{l}\text { Observation } \\
\text { Frequency }\end{array}$ & Subject Observed & $\begin{array}{c}\text { Damage } \\
\text { Threshold }\end{array}$ & Solutions \\
\hline $\begin{array}{l}\text { Bemisia } \\
\text { tabaci }\end{array}$ & $\begin{array}{c}\text { Two weeks } \\
\text { after } \\
\text { transplanting } \\
\text { until the first } \\
\text { harvest }\end{array}$ & Weekly & $\begin{array}{c}\text { - Observation on } 15 \\
\text { plants and } 3 \text { leaves per } \\
\text { plant ; } \\
\text { - Counting adults / leaf } \\
\text { - State of the leaves (leaf } \\
\text { curled in spoon) and } \\
\text { plants growth } \\
\text { (dwarfism). }\end{array}$ & $\begin{array}{l}6 \text { to } 10 \text { adults } \\
/ \text { leaf or } 5 \\
\text { infested plants } \\
\quad / 15\end{array}$ & $\begin{array}{c}\text { - Protection of } \\
\text { nurseries with insect } \\
\text { nets ; } \\
\text { - Irrigation of plants } \\
\text { by aspersion; } \\
\text { - Application PPP } \\
\text { (TITAN 25 EC, } \\
\text { ACARIUS 18 EC } \\
\text { or BIOPIQ). }\end{array}$ \\
\hline $\begin{array}{l}\text { Helicoverpa } \\
\text { armigera }\end{array}$ & $\begin{array}{c}\text { Four weeks } \\
\text { after } \\
\text { transplanting } \\
\text { until the end } \\
\text { of harvest }\end{array}$ & Weekly & $\begin{array}{l}\text { - Adults observation on } \\
\text { Yellow water traps } \\
\text { installed; } \\
\text { - Caterpillars } \\
\text { observation on leaves, } \\
\text { flowers and fruits on } 15 \\
\text { plants. }\end{array}$ & $\begin{array}{l}3 \text { to } 5 \text { adults } \\
\text { capture / week } \\
\text { or } 3 \text { to } 5 \\
\text { caterpillars / } \\
15 \text { plants }\end{array}$ & $\begin{array}{l}\text { - Suppression and } \\
\text { destruction of } \\
\text { affected organs. } \\
\text { - Application PPP } \\
\text { (BIOK 16). }\end{array}$ \\
\hline
\end{tabular}

\section{RESULTS}

\section{Assessment of cultural and phytosanitary practices in PP and IPM}

In terms of transplanting density, 360 tomato plants were transplanted in the plots of the producer 1 (PP1) and 420 in the plots of the producer 2 (PP2) compared with only 225 plants in the IPM plots for the same surface $\left(60 \mathrm{~m}^{2}\right)$. In $\mathrm{PP}$, insecticides were used to protect nurseries against insects like $B$. tabaci in contrast to IPM where insect nets were preferred. The amount of chemical fertilizers (NPK and urea) and the intensity of crop protection treatments were two times higher in PP comparatively to IPM (Table 3).

\section{Evaluation of entomofauna}

The entomofauna monitoring revealed 36 families within the three main categories, namely pests (15 families), auxiliairies (predators and parasitoids) (13 families) and pollinators (6 families) (Table 4). The relative abundances were represented according to previous fives treatments $(\mathrm{PP}=$ peasant pratices; $\mathrm{T}=$ tomato alone; $\mathrm{T}+\mathrm{B}=$ tomato with basil; $\mathrm{T}+\mathrm{G}=$ tomato with garlic and $\mathrm{T}+\mathrm{O}$ $=$ tomato with onion). More insects were collected in peasant practices $(25 \%)$ than in
IPM plots. The lowest number was observed in the tomato + onion association (16\%). The most abundant pest families were Aphididae (31\%), Agromyzidae (8\%), Acrididae (6\%), Gelechiidae (6\%), Cicadelidae (4\%) and Noctuidae (3\%). The important auxiliaries families are Coccinelidae (3\%), Sphecidae (3\%), Ichneumonidae (3\%) and Reduviidae (2\%). For pollinators, the most abundant families collected were Halictidae $(5 \%)$ and Apidae (4\%).

\section{Insect diversity (taxon family) according to practices}

A highly significant difference $(\mathrm{P}<$ 0.001) was notice between farmers' practices and IPM in terms of pests family (Table 5). More pests were collected in peasant practices $(82 \%)$ and in tomato plots without association (79\%) compared to plots where tomato was associated with aromatic plants. No significant difference was noted between treatments in terms of auxiliaries abundance that were more collected in tomato plots associated with aromatic plants (Table 5). The auxiliaries (predators + parasitoids) number was $10 \%$ that of pests in the peasant practices (PP), $17 \%$ in tomato plots without association 
(T), $53 \%$ in tomato + basil $(\mathrm{T}+\mathrm{B})$ association, $21 \%$ in tomato + garlic $(\mathrm{T}+\mathrm{G})$ association and $44 \%$ in tomato + onion $(\mathrm{T}+\mathrm{O})$ plots. As for pollinating insects, there is a significant difference $(\mathrm{P}=0.06)$ between treatments. Their number was $6 \%$ in the peasant practices (PP) and in tomato plots without association in IPM, 23\% in the tomato + basil association $(\mathrm{T}+\mathrm{B}), 11 \%$ in the tomato + garlic association $(\mathrm{T}+\mathrm{G})$ and $16 \%$ in the tomato + onion association $(\mathrm{T}+\mathrm{O})$.

\section{Evaluation of $B$. tabaci and $H$. armigera caterpillar populations}

The results showed that plots where tomato was alone (without association) are those where $B$. tabaci and $H$. armigera most develop and as quickly as possible (Figure 1a $\& 1 b)$. They also showed that whatever the association, it allows to slow and decrease the development of these pests. The infestation peak of $B$. tabaci was reached at the $49^{\text {th }}$ days after seedling in all treatments (Figure 1a). The lowest infestation level was obtained in the tomato associate to basil.

For $H$. armigera caterpillar populations (Figure 1b), the peaks of infestation were recorded on the $49^{\text {th }}$ day after transplanting outside the tomato + onion association where the peak was recorded at the $56^{\text {th }}$ day after transplanting. The low infestation was observed in tomato plots associated with onion.

\section{Evaluation of yields for PP and IPM practices}

Analysis of variance showed a highly significant difference $(\mathrm{P}<0.001)$ between $\mathrm{PP}$ and IPM in terms of production and net yield (Table 6). Fewer perforated fruits were obtained in the plots where tomato was associated with aromatic plants (basil, garlic, onion) than in the PP plots and those where tomato was alone. Also, the associated plots (tomato + basil, tomato + garlic and tomato + onion) yielded twice the tomato yield than PP plots and tomato without association. The best yield was obtained in the tomato + onion association $\left(\approx 3 \mathrm{~kg} / \mathrm{m}^{2}\right.$ of net growth yield $)$.

\section{Pesticide residues identified in tomato, water and soil samples}

Table 7 lists the active substances (a.s.) found in tomato and soil samples from Kouka peasant practices collected in 2016 (denoted PP 2016) and Bobo-Dioulasso in 2017 (denoted PP 2017). All of them were insecticides. Quantification limit (LOQ) was $0.01 \mathrm{mg} / \mathrm{kg}$ for all active substances. Residues were below the LOQ in IPM samples (tomato fruit, soil and water). Sixty and ninety percent of Kouka tomato samples contain lambdacyhalothrin and profenofos residues respectively. In the samples of BoboDioulasso, $30 \%$ contained residues of chlorpyrifos-ethyl.

In soil, hundred percent of the Kouka soil samples contained profenofos residues and $30 \%$ lambda-cyhalothrin (Table7). Chlorpyrifos-ethyl was found in $40 \%$ of soil samples collected from peasant plots of BoboDioulasso. The DDT, which use is prohibited, has also been found in $40 \%$ of soil samples from peasant practices in Bobo-Dioulasso.

\section{Risk assessment for consumers to pesticide residues}

Table 7 shows that only chlorpyrifosethyl has a residual value $(0.036 \mathrm{mg} / \mathrm{kg})$ higher than its MRL for tomatoes $(0.01$ $\mathrm{mg} / \mathrm{kg}$ ). The average weight of a tomato in the samples collected in the peasant practices was assessed and equal to $0.075 \pm 0,018 \mathrm{~kg}$. Table 8 indicates that despite exceeding MRL (360\%), PSTI remains below ARfD (0.005 $\mathrm{mg} / \mathrm{kg}$ ) for all target groups (children and adults). Therefore, there is no acute intoxication risk, neither for children nor adults who could ingest these tomatoes.

\section{Economic profitability of different tomato cropping practices}

The economic profitability of different tomato cropping practices (peasant and IPM practices) is summarized in Table 9. All IPM practices gave the better profit that peasant practices which recorded a loss of more than 3,000 FCFA. The best profit was obtained in the tomato + onion association with a profit of 5 times that of tomato without association. 
D. SON et al. / Int. J. Biol. Chem. Sci. 12(1): 101-119, 2018

Table 3: Amount of fertilizers and PPP used in peasant practices and IPM plots.

\begin{tabular}{|c|c|c|c|c|c|c|}
\hline Convenient & Practices & Surface $\left(\mathrm{m}^{2}\right)$ & Organic Manure (kg) & NPK (kg) & Urea (kg) & Average number of sprays PPP \\
\hline PP & PP & 60 & 30 & 4 & 2 & 10.5 \\
\hline \multirow{4}{*}{ IPM } & $\mathrm{T}$ & 60 & 50 & 1.5 & 0.5 & \multirow{4}{*}{6} \\
\hline & $\mathrm{T}+\mathrm{B}$ & 60 & 50 & 1.5 & 0.5 & \\
\hline & $\mathrm{T}+\mathrm{G}$ & 60 & 50 & 1.5 & 0.5 & \\
\hline & $\mathrm{T}+\mathrm{O}$ & 60 & 50 & 1.5 & 0.5 & \\
\hline
\end{tabular}

$\mathrm{PP}=$ peasant practices; $\mathrm{T}=$ tomato alone $\mathrm{T}+\mathrm{B}=$ tomato with basil $; \mathrm{T}+\mathrm{G}=$ tomato with garlic and $\mathrm{T}+\mathrm{O}=$ tomato with onion.

Table 4: Main insect families and their relative abundance on tomato plants according to practices.

\begin{tabular}{|c|c|c|c|c|c|c|c|c|c|c|c|c|c|}
\hline & \multirow[b]{2}{*}{ Insect families } & \multicolumn{2}{|c|}{$\mathbf{P P}$} & \multicolumn{2}{|c|}{$\mathbf{T}$} & \multicolumn{2}{|c|}{$\mathbf{T}+\mathbf{B}$} & \multicolumn{2}{|c|}{$\mathbf{T}+\mathbf{G}$} & \multicolumn{2}{|c|}{$\mathbf{T}+\mathbf{O}$} & \multicolumn{2}{|c|}{ Total } \\
\hline & & Abund & $\mathbf{F}(\%)$ & Abund & $\mathbf{F}(\%)$ & Abund & F $(\%)$ & Abund & $\mathbf{F}(\%)$ & Abund & $\mathbf{F}(\%)$ & Abund & $\mathbf{F}(\%)$ \\
\hline \multirow{14}{*}{$\begin{array}{l}\frac{0}{5} \\
0\end{array}$} & Acrididae & 21 & 11 & 14 & 10 & 7 & 5 & 3 & 2 & 0 & 0 & 45 & 6 \\
\hline & Agromyzidae & 16 & 8 & 11 & 8 & 8 & 5 & 21 & 14 & 3 & 2 & 59 & 8 \\
\hline & Anthomyiidae & 1 & 1 & 0 & 0 & 0 & 0 & 0 & 0 & 0 & 0 & 1 & 0 \\
\hline & Aphididae & 69 & 36 & 51 & 36 & 27 & 18 & 67 & 44 & 20 & 16 & 234 & 31 \\
\hline & Arctiidae & 2 & 1 & 2 & 1 & 3 & 2 & 1 & 1 & 0 & 0 & 8 & 1 \\
\hline & Chrysomelidae & 1 & 1 & 0 & 0 & 1 & 1 & 0 & 0 & 2 & 2 & 4 & 1 \\
\hline & Cicadellidae & 19 & 10 & 8 & 6 & 0 & 0 & 0 & 0 & 3 & 2 & 30 & 4 \\
\hline & Coreidae & 5 & 3 & 5 & 4 & 3 & 2 & 3 & 2 & 5 & 4 & 21 & 3 \\
\hline & Curculionidae & 3 & 2 & 0 & 0 & 0 & 0 & 0 & 0 & 1 & 1 & 4 & 1 \\
\hline & Diopsidae & 0 & 0 & 0 & 0 & 0 & 0 & 1 & 1 & 1 & 1 & 2 & 0 \\
\hline & Gelechiidae & 15 & 8 & 9 & 6 & 6 & 4 & 8 & 5 & 4 & 3 & 42 & 6 \\
\hline & Noctuidae & 4 & 2 & 5 & 4 & 7 & 5 & 1 & 1 & 8 & 7 & 25 & 3 \\
\hline & Pentatomidae & 7 & 4 & 1 & 1 & 7 & 5 & 2 & 1 & 5 & 4 & 22 & 3 \\
\hline & Scutelleridae & 5 & 3 & 3 & 2 & 2 & 1 & 2 & 1 & 1 & 1 & 13 & 2 \\
\hline
\end{tabular}


D. SON et al. / Int. J. Biol. Chem. Sci. 12(1): 101-119, 2018

\begin{tabular}{|c|c|c|c|c|c|c|c|c|c|c|c|c|c|}
\hline & Tephritidae & 5 & 3 & 1 & 1 & 5 & 3 & 1 & 1 & 4 & 3 & 16 & 2 \\
\hline & Total pests & 173 & 91 & 110 & 79 & 76 & 49 & 110 & 73 & 57 & 47 & 526 & 69 \\
\hline \multirow{8}{*}{ } & Asilidae & 2 & 1 & 2 & 1 & 0 & 0 & 1 & 1 & 0 & 0 & 5 & 1 \\
\hline & Coccinelidae & 2 & 1 & 2 & 1 & 7 & 5 & 6 & 4 & 7 & 6 & 24 & 3 \\
\hline & Eumenidae & 2 & 1 & 1 & 1 & 4 & 3 & 0 & 0 & 1 & 1 & 8 & 1 \\
\hline & Pompilidae & 0 & 0 & 5 & 4 & 2 & 1 & 2 & 1 & 2 & 2 & 11 & 1 \\
\hline & Reduviidae & 5 & 3 & 1 & 1 & 3 & 2 & 3 & 2 & 1 & 1 & 13 & 2 \\
\hline & Sphecidae & 0 & 0 & 5 & 4 & 7 & 5 & 6 & 4 & 4 & 3 & 22 & 3 \\
\hline & Vespidae & 0 & 0 & 0 & 0 & 1 & 1 & 0 & 0 & 2 & 2 & 3 & 0 \\
\hline & Total predators & 11 & 6 & 16 & 11 & 24 & 16 & 18 & 12 & 17 & 14 & 86 & 11 \\
\hline \multirow{7}{*}{ 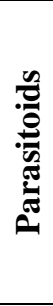 } & Chalcididae & 1 & 1 & 0 & 0 & 0 & 0 & 0 & 0 & 0 & 0 & 1 & 0 \\
\hline & Gasteruptiidae & 2 & 1 & 1 & 1 & 5 & 3 & 1 & 1 & 0 & 0 & 9 & 1 \\
\hline & Ichneumonidae & 0 & 0 & 2 & 1 & 10 & 6 & 3 & 2 & 6 & 5 & 21 & 3 \\
\hline & Mutillidae & 2 & 1 & 0 & 0 & 1 & 1 & 0 & 0 & 0 & 0 & 3 & 0 \\
\hline & Scoliidae & 2 & 1 & 0 & 0 & 0 & 0 & 1 & 1 & 1 & 1 & 4 & 1 \\
\hline & Stephanidae & 0 & 0 & 0 & 0 & 0 & 0 & 0 & 0 & 1 & 1 & 1 & 0 \\
\hline & Total parasitoids & 7 & 4 & 3 & 2 & 16 & 10 & 5 & 3 & 8 & 7 & 39 & 5 \\
\hline \multirow{7}{*}{ 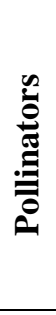 } & Andrenidae & 0 & 0 & 0 & 0 & 0 & 0 & 1 & 1 & 1 & 1 & 2 & 0 \\
\hline & Apidae & 3 & 2 & 5 & 4 & 13 & 8 & 4 & 3 & 8 & 7 & 33 & 4 \\
\hline & Collitidae & 7 & 4 & 0 & 0 & 4 & 3 & 0 & 0 & 0 & 0 & 11 & 1 \\
\hline & Halictidae & 3 & 2 & 2 & 1 & 18 & 12 & 10 & 7 & 4 & 3 & 37 & 5 \\
\hline & Megachilidae & 0 & 0 & 0 & 0 & 0 & 0 & 1 & 1 & 3 & 2 & 4 & 1 \\
\hline & Syrphidae & 0 & 0 & 1 & 1 & 0 & 0 & 0 & 0 & 0 & 0 & 1 & 0 \\
\hline & Total pollinators & 13 & 7 & 8 & 6 & 35 & 23 & 16 & 11 & 16 & 13 & 88 & 12 \\
\hline \multirow{4}{*}{$\stackrel{\bar{d}}{\grave{0}}$} & Stratiomyidae & 7 & 4 & 2 & 1 & 0 & 0 & 0 & 0 & 0 & 0 & 9 & 1 \\
\hline & Formicidae & 0 & 0 & 1 & 1 & 3 & 2 & 2 & 1 & 3 & 2 & 9 & 1 \\
\hline & Total other & 7 & 4 & 3 & 2 & 3 & 2 & 2 & 1 & 3 & 2 & 18 & 2 \\
\hline & Total & 211 & 100 & 140 & 100 & 154 & 100 & 151 & 100 & 101 & 83 & 757 & 100 \\
\hline
\end{tabular}

Abund $=$ abundance $; \mathrm{F}(\%)=$ frequency $)(\mathrm{PP}=$ peasant practices $; \mathrm{T}=$ tomato alone; $\mathrm{T}+\mathrm{B}=$ tomato with basil; $\mathrm{T}+\mathrm{G}=$ tomato with garlic and $\mathrm{T}+\mathrm{O}=$ tomato with onion. 
Table 5: Distribution of insect types (expressed in number of families) collected in tomato plots according to practices.

\begin{tabular}{|c|c|c|c|c|c|c|}
\hline Treatments & Observation number & Pests \pm SD & Predators \pm SD & Parasitoids \pm SD & Pollinators \pm SD & Others \pm SD \\
\hline $\mathrm{PP}$ & 5 & $34.60^{\mathrm{a}} \pm 10.24$ & $2.20 \pm 2.68$ & $1.40 \pm 0.89$ & $2.60^{\mathrm{ab}} \pm 1.67$ & $1.40 \pm 2.19$ \\
\hline $\mathrm{T}$ & 5 & $22.00^{\mathrm{b}} \pm 5.52$ & $3.20 \pm 3.83$ & $0.60 \pm 0.55$ & $1.60^{\mathrm{a}} \pm 1.51$ & $0.60 \pm 0.89$ \\
\hline $\mathrm{T}+\mathrm{B}$ & 5 & $15.20^{\mathrm{bc}} \pm 4.87$ & $4.80 \pm 2.95$ & $3.20 \pm 4.32$ & $7.00^{b} \pm 5.24$ & $0.60 \pm 0.89$ \\
\hline $\mathrm{T}+\mathrm{G}$ & 5 & $22.00^{\mathrm{b}} \pm 6.04$ & $3.60 \pm 1.95$ & $1.00 \pm 1.41$ & $3.20^{\mathrm{ab}} \pm 2.58$ & $0.40 \pm 0.55$ \\
\hline $\mathrm{T}+\mathrm{O}$ & 5 & $11.40^{\mathrm{c}} \pm 4.56$ & $3.40 \pm 1.14$ & $1.60 \pm 2.07$ & $3.20^{\mathrm{ab}} \pm 1.78$ & $0.60 \pm 0.89$ \\
\hline $\mathrm{P}$ & & $<.001$ & 0.66 & 0.40 & 0.06 & 0.74 \\
\hline
\end{tabular}

$\mathrm{PP}=$ peasant pratices; $\mathrm{T}=$ tomato alone; $\mathrm{T}+\mathrm{B}=$ tomato with basil; $\mathrm{T}+\mathrm{G}=$ tomato with garlic and $\mathrm{T}+\mathrm{O}=$ tomato with onion

The results followed by the same letter in the same column are not significantly different at the 5\% threshold (Tukey's test). SD = standard deviation.

Table 6: Average weight of healthy and perforated ripe fruit and net growth yield depending on practices in $60 \mathrm{~m}^{2}$.

\begin{tabular}{|c|c|c|c|c|}
\hline Treatments & $\begin{array}{l}\text { Average weight of perforated fruit } \\
\qquad(\mathrm{kg} \pm \mathrm{SD})\end{array}$ & $\begin{array}{l}\text { Average weight of healthy fruit } \\
(\mathrm{kg} \pm \mathrm{SD})\end{array}$ & Yield $\left(\mathrm{kg} / \mathrm{m}^{2} \pm \mathrm{SD}\right)$ & $\begin{array}{c}\text { Net growth yield }\left(\mathrm{kg} / \mathrm{m}^{2} \pm\right. \\
\text { SD) }\end{array}$ \\
\hline PP & $4.87^{\mathrm{c}} \pm 0.55$ & $22.42^{\mathrm{a}} \pm 1.40$ & $1.71^{\mathrm{a}} \pm 0.07$ & $1.40^{\mathrm{a}} \pm 0.09$ \\
\hline $\mathrm{T}$ & $2.67^{\mathrm{b}} \pm 0.28$ & $30.75^{\mathrm{b}} \pm 4.14$ & $2.09^{b} \pm 0.26$ & $1.92^{\mathrm{b}} \pm 0.26$ \\
\hline $\mathrm{T}+\mathrm{B}$ & $1.89^{\mathrm{a}} \pm 0.20$ & $35.88^{\mathrm{bc}} \pm 3.82$ & $2.36^{\mathrm{bc}} \pm 0.24$ & $2.24^{\mathrm{bc}} \pm 0.23$ \\
\hline $\mathrm{T}+\mathrm{G}$ & $2.09^{\mathrm{a}} \pm 0.21$ & $39.66^{\mathrm{cd}} \pm 3.97$ & $2.61^{\mathrm{cd}} \pm 0.26$ & $2.48^{\mathrm{cd}} \pm 0.25$ \\
\hline $\mathrm{T}+\mathrm{O}$ & $2.31^{\mathrm{ab}} \pm 0.21$ & $43.73^{\mathrm{d}} \pm 3.70$ & $2.88^{\mathrm{d}} \pm 0.25$ & $2.73^{\mathrm{d}} \pm 0.23$ \\
\hline $\mathrm{P}$ & $<0.001$ & $<0.001$ & $<0.001$ & $<0.001$ \\
\hline
\end{tabular}

$\mathrm{PP}=$ peasant practices; $\mathrm{T}=$ tomato alone; $\mathrm{T}+\mathrm{B}=$ tomato with basil; $\mathrm{T}+\mathrm{G}=$ tomato with garlic and $\mathrm{T}+\mathrm{O}=$ tomato with onion

The results followed by the same letter in the same column are not significantly different at the $5 \%$ threshold (Tukey's test). SD $=$ standard deviation. 
Table 7: Residues in tomato and soil samples taken from producers plots in Kouka in 2016 (PP 2016) and Bobo-Dioulasso in 2017 (PP 2017 ), with their maximum residue limit for tomatoes (MRL, $\mathrm{mg} / \mathrm{kg}$ ), acute reference dose (ARfD, $\mathrm{mg} / \mathrm{kg}$ bw), half-life time in ground in aerobic condition (TD 50 (days) adsorption coefficient on organic carbon (Koc, mL/kg) according to European pesticides database (EU_Pesticides Database, 2017) and SAgE pesticides (2017).

\begin{tabular}{|c|c|c|c|c|c|c|c|c|}
\hline \multirow[t]{2}{*}{ Active substances } & \multicolumn{4}{|c|}{$\begin{array}{c}\text { Average concentration of active substances in tomato } \\
\text { samples }(\mathrm{mg} / \mathrm{kg}) \text { and percentage of samples affected in } 10 \\
\text { samples }\end{array}$} & \multicolumn{4}{|c|}{$\begin{array}{l}\text { Average concentration of active substances in soil samples } \\
(\mathrm{mg} / \mathrm{kg}) \text { and percentage of samples affected in } 10 \text { samples }\end{array}$} \\
\hline & PP (2016) & PP (2017) & MRL & ARfD & PP (2016) & PP (2017) & TD50 (days) & Koc $(\mathrm{mL} / \mathrm{g})$ \\
\hline Acetamiprid & $0.011(10 \%)$ & $<0.010(0 \%)$ & 0.5 & 0.1 & $0.016(10 \%)$ & $<0.010(0 \%)$ & 4.5 & 157.0 \\
\hline Chlorpyrifos-ethyl & $<0.010(0 \%)$ & $0.036(30 \%)$ & 0.01 & 0.005 & $<0.010(0 \%)$ & $0.028(40 \%)$ & 95.5 & 360.0 \\
\hline Cypermethrin & $0.014(30 \%)$ & $<0.010(0 \%)$ & 0.5 & 0.2 & $<0.010(0 \%)$ & $<0.010(0 \%)$ & 54.5 & 20800.0 \\
\hline DDT & $<0.010(0 \%)$ & $<0.010(0 \%)$ & 0.05 & NA & $<0.010(0 \%)$ & $0.025(40 \%)$ & 2 to 15 years & 172000.0 \\
\hline Imidacloprid & $<0.010(0 \%)$ & $<0.010(0 \%)$ & 0.5 & 0.08 & $<0.010(0 \%)$ & $0.066(10 \%)$ & 336.5 & 41.0 \\
\hline Lambda-cyhalothrin & $0.021(60 \%)$ & $<0.010(0 \%)$ & 0.1 & 0.005 & $0.027(30 \%)$ & $<0.010(0 \%)$ & 36.9 & 70100.0 \\
\hline Profenofos & $0.111(90 \%)$ & $<0.010(0 \%)$ & 10 & 1 & $0.042(100 \%)$ & $<0.010(0 \%)$ & 7.0 & 869 to 3,162 \\
\hline
\end{tabular}




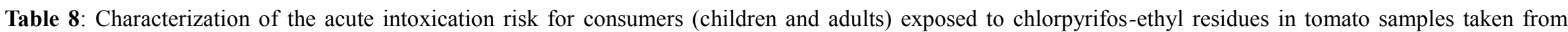
producers in Bobo-Dioulasso (Burkina Faso).

\begin{tabular}{|c|c|c|}
\hline Parameters used in the PSTI Model & Children & Adults \\
\hline $\mathrm{LP}$ (P97.5, in kg/person) & 0.18 & 0.45 \\
\hline Body weight (bw, in kg) & 10 & 60 \\
\hline Unit weight of tomato ( $\mathrm{U}$, in $\mathrm{kg}$ data collected) & 0.075 & 0.075 \\
\hline Variability factor (v) & 7 & 7 \\
\hline Processing factor (Pf, default value) & 1 & 1 \\
\hline PSTI (in $\mathrm{mg} / \mathrm{kg}$ bw) & 0.002 & 0.001 \\
\hline$\%$ ARfD & $40 \%$ & $20 \%$ \\
\hline
\end{tabular}

Table 9: Economic profitability of peasant and IPM practices in tomato production among producers on $60 \mathrm{~m}^{2}$.

\begin{tabular}{|c|c|c|c|c|c|}
\hline & PP & $\mathbf{T}$ & $\mathbf{T}+\mathbf{B}$ & $\mathbf{T}+\mathbf{G}$ & $\mathbf{T}+\mathbf{O}$ \\
\hline \multicolumn{6}{|l|}{ Expenses (FCFA) } \\
\hline Seeds & 1500 & 720 & 1520 & 2720 & 2120 \\
\hline Fertilizers (organic and mineral) & 3690 & 1420 & 1420 & 1420 & 1420 \\
\hline Phytosanitary protection (inputs + treatment costs) & 10800 & 2725 & 2725 & 2725 & 2725 \\
\hline Weekly observation of pests & 0 & 2500 & 2500 & 2500 & 2500 \\
\hline Other charges (water, weeding, harvest) package & 11750 & 11750 & 11750 & 11750 & 11750 \\
\hline
\end{tabular}


D. SON et al. / Int. J. Biol. Chem. Sci. 12(1): 101-119, 2018

\begin{tabular}{|c|c|c|c|c|c|c|}
\hline \multirow{2}{*}{ Total expenditure } & FCFA & 27740 & 19115 & 19915 & $\begin{array}{c}21115 \\
22\end{array}$ & \multirow{2}{*}{\begin{tabular}{|c|}
20515 \\
31 \\
\end{tabular}} \\
\hline & Euro & 42 & 29 & 30 & 32 & \\
\hline \multicolumn{7}{|l|}{ Sale (FCFA) } \\
\hline \multirow{2}{*}{ Tomato } & Quantity (kg) & 67 & 92 & 108 & 119 & 131 \\
\hline & Value (FCFA) & 16815 & 23064 & 26909 & 29746 & 32798 \\
\hline \multirow{2}{*}{ Onion } & Quantity (kg) & 0 & 0 & 0 & 0 & 15 \\
\hline & Value (FCFA) & 0 & 0 & 0 & 0 & 7500 \\
\hline \multirow{2}{*}{ Garlic } & Quantity (kg) & 0 & 0 & 0 & 3 & 0 \\
\hline & Value (FCFA) & 0 & 0 & 0 & 3000 & 0 \\
\hline \multirow{2}{*}{ Basil } & Quantity (kg) & 0 & 0 & 15 & 0 & 0 \\
\hline & Value (FCFA) & 0 & 0 & 2250 & 0 & 0 \\
\hline \multirow{2}{*}{ Lettuce } & Quantity (kg) & 15 & 0 & 0 & 0 & 0 \\
\hline & Value (FCFA) & 7500 & 0 & 0 & 0 & 0 \\
\hline \multirow{2}{*}{ Sales value } & FCFA & 24315 & 23064 & 29159 & 32746 & 40298 \\
\hline & $\begin{array}{l}\text { Euro } \\
\end{array}$ & 37 & 35 & 44 & 50 & 61 \\
\hline \multirow{2}{*}{ Profit } & FCFA & -3425 & 3949 & 9244 & 11631 & 19783 \\
\hline & Euro & -5 & 6 & 14 & 18 & 30 \\
\hline
\end{tabular}

$\mathrm{PP}=$ peasant practices; $\mathrm{T}=$ tomato alone; $\mathrm{T}+\mathrm{B}=$ tomato with basil; $\mathrm{T}+\mathrm{G}=$ tomato with garlic and $\mathrm{T}+\mathrm{O}=$ tomato with onion. 


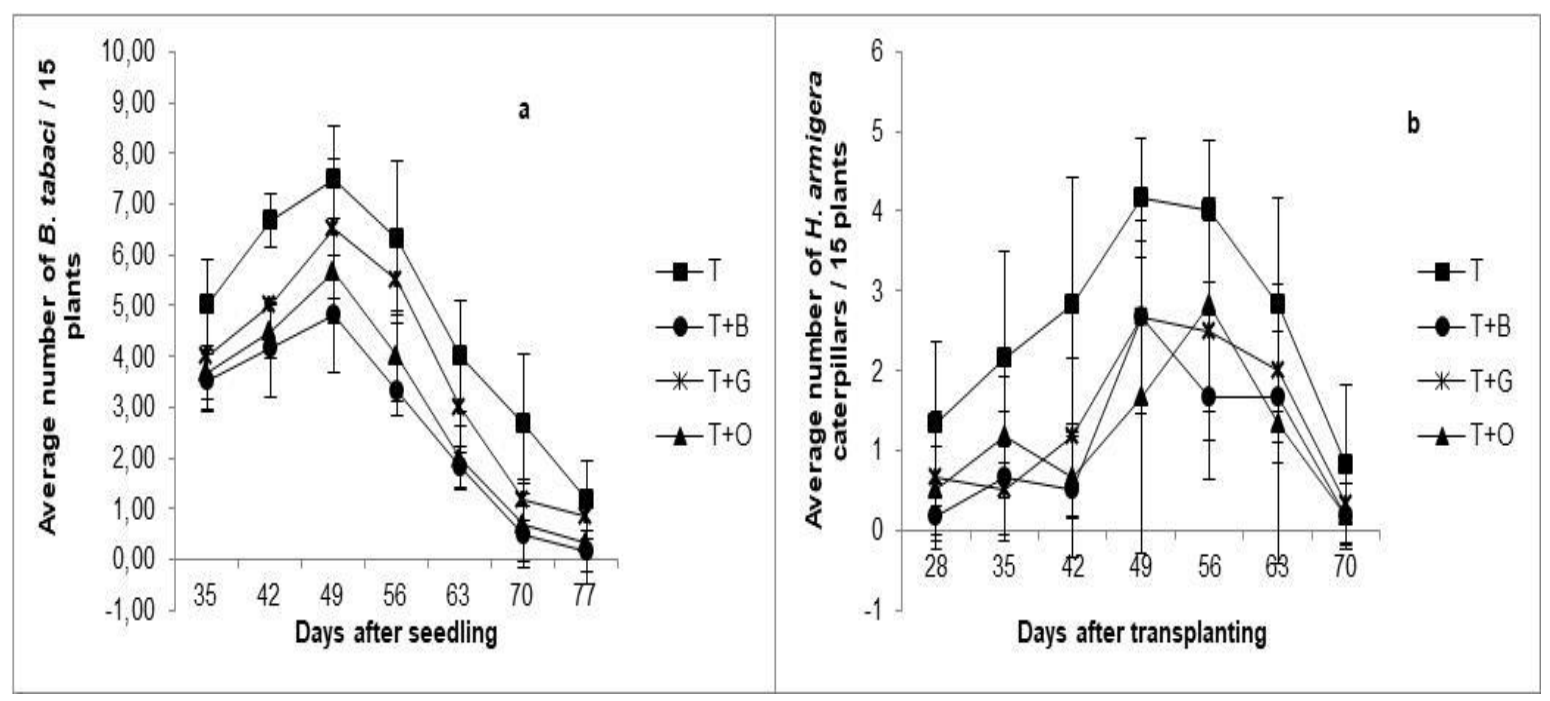

Figure 1: Dynamics of B.tabaci (a) and H. armigera caterpillars (b) populations according to practices. ( $\mathrm{T}=$ tomato alone; $\mathrm{T}+\mathrm{B}=$ tomato with basil; $\mathrm{T}+\mathrm{G}=$ tomato with garlic and $\mathrm{T}+\mathrm{O}=$ tomato with onion).

\section{DISCUSSION}

\section{Assessment of cultural and phytosanitary practices}

The observation of cultural peasant practices revealed the use of pests-sensitive varieties, a high density of transplanting and an excessive use of nitrogen fertilizers compared with IPM. The excessive use of mineral fertilizers by producers in vegetable production has been reported by Atidegla et al. (2017) in Benin. Poor practices make plants more susceptible to diseases (bacterial wilt, root rot, ...) and to pests (whiteflies and mites) (Nicot et al., 2012; Raynal et al., 2014). This may partly explain the intensification of phytosanitary treatments observed in peasant practices (Son et al., 2017b).

\section{Pests infestation and tomato yield in PP and IPM}

More pests have been observed in peasant practices and in the tomato plots without association compared with plots where tomato was associated to basil, garlic or onion. Results confirm previous observations showing a clear relation between the diversification of plants in the same plot and a depressed development of the pest populations and an increased presence of their natural enemies (Letourneau et al., 2011; Parker et al., 2013). Several authors (Auger et al., 2002; Rhino et al., 2014; Khafagy, 2015) reported that aromatic plants contain volatile compounds that can disrupt the development of the pest and promote the growth of the host plant.

The first overgrowth of whiteflies and other pests was observed from the second to the third week after transplanting. The peak coincides with the period of tomato vegetative development when populations of whiteflies, aphids and Liriomyza sp. are important. Our results corroborate those of Nzi et al. (2010) who observed an overgrowth of whiteflies on the tomato during this period. The second peak was observed between the $35^{\text {th }}$ to $56^{\text {th }}$ day after transplanting, a period corresponding to the flowering-fruiting of tomato and to outbreaks of $H$. armigera and $T$. absoluta. Our results are in line with those of Adje et al. (2009) who observed a high overgrowth of $H$. armigera between the $40^{\text {th }}$ and $60^{\text {th }}$ day after transplanting.

For yields, the best results were obtained in the plots where tomato was associated with aromatic plants. This shows that a good diversification of plants in the same plot, coupled with the respect of good 
cropping (transplanting density, fertilization) and phytosanitary (use of pesticides recommended at the right times) practices, make it possible to control pests and to obtain interesting yields (Poveda et al., 2008).

\section{Pesticide residues in tomatoes and risk for consumers}

Pesticide residues were found in several samples of tomatoes and soils. This could be due to the use of pesticides that are not recommended to be used in vegetable production such as cotton pesticides who have a high concentration of active substances and a high persistence in vegetables, or nonobservance of doses recommended and preharvest delay (Ahouangninou et al., 2011; Son et al., 2017b). Pesticides residues sometimes exceeding MRLs have also been found in vegetables by other authors in Burkina Faso and other countries (Bempah et al., 2011; Lehmann et al., 2017). The pesticide residues levels measured in soil were found higher than residues in fruits. This can be explained by the fact that soil is directly exposed to pesticides and 10 to $70 \%$ of pesticide loss could reach the soil during a foliar spraying (Aubertot et al., 2005).The fact of finding DDT residues in the soil that was not used by producers, explains the previous pollution of some soils of Burkina Faso by pesticides with a very high TD50.

No pesticide residues above the limit of quantification were found in the water samples. This could be explained by the high Koc values of the pesticides used by producers. Indeed, when Koc is high, the transfer of pesticides into the soil is limited and the potential for groundwater contamination is lower (Arias-Estévez et al., 2008). Our results are in line with those of Del Prado-Lu (2015) who found no pesticide residues on 26 water samples analyzed and explained this by the high Koc of active substances used by producers.

The risk assessment of consumers' exposure to pesticide residues by PSTI method shows that despite a high concentration of chlorpyrifos-ethyl in tomatoes (360\% of MRL), there is no acute intoxication risk, neither for children nor adults. However, continuous consumption of fruits with high pesticide residues concentrations could lead to adverse effects on human health. Once ingested, chlorpyrifos passes rapidly from intestines to bloodstream where it is distributed to the rest of body (ATSDR, 1997). Chlorpyrifos affects the nervous system by inhibiting the activity of cholinesterase, an enzyme necessary for the proper functioning of the nervous system regardless the absorption pathway or duration of exposure (US-EPA, 2000).

\section{Conclusion}

The result as reported herein showed that the application of recommended farming practices and integrated pest management strategies can allow the reduction of plant protection products used in tomato crops compared with usual peasant practices in Burkina Faso which have been characterized by high transplanting densities, excess and misuse of nitrogen fertilizers and pesticides. In terms of pest infestation and yields, results demonstrate the interest of aromatic plants associated with tomato: the yields and profitability are increased. Additionally, these better practices can reduce the exposure of the producer to pesticides and lead to a higher level of protection for the consumer health and the environment.

In particular, the tomato-onion association raised not only the best yield and but also the best economic performances. These two speculations being the most cultivated in Burkina Faso, the acceptability by the producers of such an association could be easily integrated due to its good sustainability. However, in order to implement the integrated pest management strategies, it will be crucial for sustainable success to train the producers on good practices, identification of pests, efficacy and selectivity of pesticides and their choice according to the targets, the number of auxiliaries and the economic threshold. 


\section{COMPETING INTERESTS}

The authors declare that they have no competing interests.

\section{AUTHORS' CONTRIBUTIONS}

BS was the promoter of this work. All authors contributed significantly to the successful completion of this research work both intellectually and financially. Accordingly, they conceived and designed the study plan. DS conducted sampling, analyzed the data, and wrote the initial manuscript. BS guided this study and provided revisions on the manuscript. Finally, all the authors have read and approved the final manuscript.

\section{ACKNOWLEDGEMENTS}

We would like to thank Professor Frédéric FRANCIS, head of Functional and Evolutionary Entomology laboratory in Gembloux Agro-Bio Tech and his team for supporting us in the determination of tomato entomofauna of Burkina Faso. Our thanks also go to all those who contributed to correct English, especially Professor Georges LOGNAY of Gembloux Agro-Bio Tech.

\section{REFERENCES}

Adje K, Djidji AH, Fondio L, N'zi JC, Kouamé C. 2009. Efficacité des traitements phytosanitaires contre les ravageurs et maladies de quatre variétés de tomate au centre de la côte d'ivoire. Agron. Africaine., 21(2): 165-172.

Agbohessi TP, Toko II, Kestemont P. 2012. État des lieux de la contamination des écosystèmes aquatiques par les pesticides organochlorés dans le Bassin cotonnier béninois. Cah. Agric., 21(1): 46-56. doi : 10.1684/agr.2012.0535

Ahouangninou C, Fayomi BE, Martin T, 2011. Evaluation des risques sanitaires et environnementaux des pratiques phytosanitaires des producteurs maraîchers dans la commune rurale de Tori-Bossito (Sud-Bénin). Cah. Agric., 20(3): 216-222. DOI: 10.1684/agr.2011. 0485
Anastassiades M, Lehotay SJ, Stajnbaher D, Schenck FJ, 2003. Fast and easy multiresidue method employing acetonitrile extraction/partitioning and "dispersive solid-phase extraction" for the determination of pesticide residues in produce. J. AOAC Int., 86(2): 412-431.

Arabaci O, Bayram E, 2004. The effet of nitrogen fertilization and different plant densities on some agronomic and technologic of Ocimum basilicum L. (Basil). J. Agron., 3(4): 255-262.

Arias-Estévez M, López-Periago E, MartínezCarballo E, Simal-Gándara J, Mejuto JC, García-Río L. 2008. The mobility and degradation of pesticides in soils and the pollution of groundwater resources. Agric. Ecosyst. Environ., 123(4): 247260. DOI:10.1016/j.agee.2007.07.011

Atidegla SC, Bonou W, Agbossou EK. 2017. Relations entre perceptions des producteurs et surfertilisation en maraichage urbain et péri urbain au Bénin. Int. J. Biol. Chem. Sci., 11(5): 2106-2118. DOI: http://dx.doi.org/ 10.4314/ijbcs.v11i5.14

ATSDR (Agency for Toxic Substances and Disease Registry). 1997. Toxicological Profile for Chlorpyrifos, U.S. Department of health and human services, $217 \mathrm{p}$.

Aubertot JN, Barbier JM, Carpentier A, Gril JJ, Guichard L, Lucas P, Savary S, Savini IVM. 2005. Agriculture et environnement. Réduire l'utilisation des pesticides et en limiter les impacts environnementaux Expertise scientifique collective, synthèse du rapport, INRA et Cemagref, France, 64 p.

Auger J, Dugravot S, Naudin A. 2002. Utilisation des composes allelochimiques des Allium en tant qu'insecticides. IOBC wprs., 25: 1-13.

Bempah C.K., Buah-Kwofie A., Denutsui D., Asomaning J, Tutu AO. 2011. Monitoring of pesticide residues in fruits 
and vegetables and related health risk assessment in Kumasi metropolis, Ghana. Res. J. Environ. Earth Sci., 3(6): 761-771.

Brévault T, Beyo J, Nibouche SVM. 2007. La résistance des insectes aux insecticides: problématique et enjeux en Afrique centrale, Cirad-Prasac, France, 6 p.

Chen C, Qian Y, Chen Q, Tao C, Li C, Li Y, 2011. Evaluation of pesticide residues in fruits and vegetables from Xiamen, China. Food Control., 22(7): 1114-1120. DOI:10.1016/j.foodcont.2011.01.007

Chougourou DC, Agbaka A, Adjakpa JB, Koutchika RE, Kponhinto UG, Adjalia EJN, 2012. Inventaire préliminaire de l'entomofaune des champs de tomates (Lycopersicon esculentum Mill) dans la Commune de Djakotomey au Bénin. Int. J. Biol. Chem. Sci., 6(4): 1798-1804. DOI : http://dx.doi.org/10.4314/ijbcs. v6i4.34

Dahlin I, Vucetic A, Ninkovic V. 2015. Changed host plant volatile emissions induced by chemical interaction between unattacked plants reduce aphid plant acceptance with intermorph variation. $J$. Pest Sci., 88(2): 249-257. DOI 10.1007/s10340-014-0625-z

Del Prado-Lu JL. 2015. Insecticide residues in soil, water, and eggplant fruits and farmers' Health effects due to exposure to pesticides. Environ. Health Prev. Med., 20(1): 53-62. DOI 10.1007/s12199-014-0425-3

Dross C. 2012. Impact de plantes aromatiques associées à la tomate sur les populations d'aleurodes\# Bemisia tabaci, Master Sciences et Technologies du Vivant et de l'Environnement, CIRAD, France, 45 p.

El-Ghammam M, Nasser HMA, Wahba MN. 2016. Effect of intercropping of two aromatic plants and two treatments against infestation of Liriomyza Trifolli ( Burgess ) on two green pea plants and economic evaluation of yield. Middle
East J. Agric. Res., 5(4): 455-461.

EU-Pesticides Database. 2017. European pesticides database. http://ec.europa.eu/ food/plant/pesticides/eu-pesticidesdatabase/public/?event=activesubstance. detail\&language $=\mathrm{EN} \&$ selectedID $=1755$, (12/11/2017).

FAO. 2012a. Code international de conduite pour la distribution et l'utilisation des pesticides. Directives pour la prévention et la gestion de la résistance aux pesticides, FAO, 62 p.

FAO. 2012b. La Production et Protection Intégrées appliquée aux cultures maraîchères en Afrique soudanosahélienne, $158 \mathrm{p}$.

Fernandes FL, Bacci L, Fernandes MS. 2010. Impact and selectivity of insecticides to predators and parasitoids. EntomoBrasilis., 3(1): 1-10.

Hilje L, Costa HS, Stansly PA. 2001. Cultural practices for managing Bemisia tabaci and associated viral diseases. Crop Prot., 20(9): 801-812.

Hooks CRR, Johnson MW. 2003. Impact of agricultural diversification on the insect community of cruciferous crops. Crop Prot., 22: 223-238.

Jaloux B. 2011. Cultures associées et contrôle des populations de pucerons, mécanismes et perspectives, Journées Techniques Fruits et Légumes Biologiques -7 \& 8 décembre 2011 Rennes, France, 76-80.

Kenny GJ, Chapman RB. 1988. Effects of an intercrop on the insect pests, yield, and quality of cabbage. New Zeal. J. Exp. Agric., 16(1): 67-72. DOI: 10.1080/03015521.1988.10425616

Khafagy IF. 2015. The role of some aromatic plants intercropping on Tuta absoluta infestation and the associated predators on tomato. Egy. J. Plant Pro. Res., 3(2): 37-53.

Konaté G, Barro N, Fargette D, Swanson M.M. Harrison BD. 1995. Occurrence of 
whitefly-transmitted geminiviruses in crops in Burkina Faso, and their serological detection and differentiation. Ann. Appl. Biol., 126: 121-130.

Lehmann E, Turrero N, Kolia M, Konaté Y, De Alencastro LF. 2017. Dietary risk assessment of pesticides from vegetables and drinking water in gardening areas in Burkina Faso. Sci. Total Environ., 601602: 1208-1216. DOI: http://dx.doi.org/ 10.1016/j.scitotenv.2017.05.285

Letourneau DK, Armbrecht I, Rivera BS, Lerma JM, Carmona EJ, Daza MC, Escobar S, Galindo V, Gutiérrez C, Lopez SD, Mejia JL, Rangel AMA, Rangel JH, Rivera L, Saavedra CA, Torres AM, Trujillo RA. 2011. Does plant diversity benefit agroecosystems? A synthetic review. Ecol. Appl., 21(1): 9-21.

MARHASA. 2014. Superficies et Production Maraîchère par Région (campagne 2013-2014). Ministère de l'Agriculture, des Ressources Halieutiques, de l'Assainissement et de la Sécurité Alimentaire, Ouagadougou, Burkina Faso.

Martin T, Germain OO, Hala-N'Klo, Vassal JM, Vaissayre M. 2000. Pyrethroid resistance in the cotton bollworm, Helicoverpa armigera (Hübner), in West Africa. Pest Manag. Sci., 56: 549-554.

McCall PJ, Swann RL, Laskowski DA, Unger SM, Vrona SA, Dishburger HJ, 1980. Estimation of chemical mobility in soil from liquid chromatographic retention times. Bull. Environ. Contam. Toxicol., 24(1): 190-195.

Medeiros MA, Sujii ER, Morais HC. 2009. Effect of plant diversification on abundance of South American tomato pinworm and predators in two cropping systems. Hortic. Bras., 27(3): 300-306.

Naré RWA, Savadogo PW, Gnankambary Z, Nacro HBSMP. 2015. Analyzing Risks Related to the Use of Pesticides in
Vegetable Gardens in Burkina Faso. Agric. For. Fish., 4(4): 165-172. DOI: 10.11648/j.aff.20150404.13

Ngom S, Traoré S, Thiam MB, Anastasie M. 2012. Contamination des produits agricoles et de la nappe phréatique par les pesticides dans la zone des Niayes au Sénégal. Rev. Sci. Technol., 25: 119130.

Nicot PC, Fabre R, Lebkara T, Ozayou S, Abro MA, Duffaud M, Lecompte F, Jeannequin B. 2012. Manipulating nitrogen fertilization for the management of diseases in the tomato greenhouse: what perspectives for IPM? IOBC-WPRS Bull., 80: 333-338.

Nzi JC, Kouamé C, N'Guetta ASP, Fondio L, Djidji AH, Sangaré A. 2010. Evolution des populations de Bemisia tabaci Genn . selon les variétés de tomate (Solanum lycopersicum L .) au Centre de la Côte d'Ivoire. Sci. Nat., 7(1): 31-40.

Ofori ESK, Yeboah S, Nunoo J, Quartey EK, Torgby-Tetteh W, Gasu EKEEA. 2014. Preliminary studies of insect diversity and abundance on twelve accessions of tomato, Solanum lycopersicon L. Grown in a coastal savannah agro ecological zone. J. Agric. Sci., 6(8): 72-82. doi:10.5539/jas.v6n8p72

Ouattara A, Tiendrébéogo F, Lefeuvre P, Claverie S, Hoareau M, Traoré EV, Barro N, Traoré O, Lett J-M. 2017. Tomato leaf curl Burkina Faso virus: a novel tomato-infecting monopartite begomovirus from Burkina Faso. Arch. Virol., 162(5): 1427-1429. DOI: 10.1007/s00705-017-3231-6

Ouattara B, Savadogo PW, Traoré O, Koulibaly B, Sedogo PM, Traoré AS. 2010. Effet des pesticides sur l'activité microbienne d'un sol ferrugineux tropical du Burkina Faso. Cameroon J. Exp. Biol., 6(1):11-20.

Parker JE, Snyder WE, Hamilton GC, Rodriguez-Saona C. 2013. Companion 
Planting and Insect Pest Control. In Weed and Pest Control-Conventional and New Challenges, Sonia Soloneski S, Larramendy M (eds). InTech; 1-30.

Perrin RM, Phillips ML. 1978. Some effects of mixed cropping on the populationdynamics of insect pests. Entomol. Exp. Appl., 24: 385-393.

Poveda K, Gomez M, Martinez E. 2008. Diversification practices: their effect on pest regulation and production. Rev. Colomb. Entomol., 34(2): 131-144.

Raynal C, Julhia L, Nicot P. 2014. Fertilisation et sensibilité des cultures de laitue et de tomate aux bioagresseurs. Innov. Agron., 34: 1-17.

Rhino B, Dross C, Momperousse RJ, Thibaut C, Verchere A, Fernandes P. 2014. Intérêt du basilic pour la gestion agroécologique de l'aleurode. Les Cah. du CAEC / PRAM., 12: 1- 6.

SAgE pesticides. 2017. Toxicité des substances actives. http://www.sagepesticides.qc.ca/Recherc he/RechercheMatiere, (12/11/2017).

Schiffers B. 2011. Itinéraire technique de la tomae cerise (Lycopersicon esculentum), COLEACP/PIP, $46 \mathrm{p}$.

Schiffers B, Mar A. 2011. Sécurité des Opérateurs et Bonnes Pratiques Phytosanitaires, Manuel $\mathrm{n}^{\circ} 4$ : COLEACP/PIP Press. Bruxelles /
Belgique: Programme PIP/COLEACP, $246 \mathrm{p}$.

Schuster DJ. 2004. Squash as a trap crop to protect tomato from whitefly-vectored tomato yellow leaf curl. Int. J. Pest Manag., $\quad$ 50(4): $\quad 281-284 . \quad$ DOI: 10.1080/09670870412331284591

Son D, Bonzi S, Somda I, Bawin T, Boukraa $\mathrm{S}$, Verheggen F, Francis F, Legreve A, Schiffers B. 2017a. First Record of Tuta absoluta (Meyrick, 1917) (Lepidoptera: Gelechiidae) in Burkina Faso. African Entomol., 25(1): 259-263. DOI: http://dx.doi.org/10.4001/003.025.0259

Son D, Somda I, Legreve A, Schiffers B. 2017b. Pratiques phytosanitaires des producteurs de tomates du Burkina Faso et risques pour la santé et l'environnement. Cah. Agric., 26(2). DOI: $10.1051 /$ cagri/2017010

Tarla DN, Meutchieye F, Assako VA, Fontem DA, Kome JJA. 2013. Exposure of market gardeners during pesticide application in the western highlands of Cameroon. Sch. J. Agric. Sci., 3(90): 172-177. DOI: 10.15640/jaes.v4n2a10

TECHNISEM. 2016. Semences potagères, Longué-Jumelles, France, 63 p.

US-EPA (U.S. Environmental Protection Agency). 2000. Human Health Risk Assessment Chlorpyrifos, US-EPA; 139. 